\title{
EFFECTS OF TRAFFIC CONTROL ON THE SOIL PHYSICAL QUALITY AND THE CULTIVATION OF SUGARCANE ${ }^{(1)}$
}

\author{
Gustavo Soares de Souza ${ }^{(2)}$, Zigomar Menezes de Souza ${ }^{(3)}$, Reginaldo Barboza da Silva ${ }^{(4)}$, \\ Ronny Sobreira Barbosa ${ }^{(5)}$ \& Fernando Silva Araújo ${ }^{(6)}$
}

\begin{abstract}
SUMMARY
The cultivation of sugarcane with intensive use of machinery, especially for harvest, induces soil compaction, affecting the crop development. The control of agricultural traffic is an alternative of management in the sector, with a view to preserve the soil physical quality, resulting in increased sugarcane root growth, productivity and technological quality. The objective of this study was to evaluate the physical quality of an Oxisol with and without control traffic and the resulting effects on sugarcane root development, productivity and technological quality. The following managements were tested: no traffic control (NTC), traffic control consisting of an adjustment of the track width of the tractor and sugarcane trailer (TC1) and traffic control consisting of an adjustment of the track width of the tractor and trailer and use of an autopilot (TC2). Soil samples were collected (layers $0.00-0.10 ; 0.10-0.20$ and $0.20-0.30 \mathrm{~m}$ ) in the plant rows, inter-row center and seedbed region, $0.30 \mathrm{~m}$ away from the plant row. The productivity was measured with a specific weighing scale. The technological variables of sugarcane were measured in each plot. Soil cores were collected to analyze the root system. In TC2, the soil bulk density and compaction degree were lowest and total porosity and macroporosity highest in the plant row. Soil penetration resistance in the plant row, was less than $2 \mathrm{MPa}$ in TC1 and TC2. Soil aggregation and total organic carbon did not differ between the management systems. The root surface and volume were increased in TC1 and TC2, with higher productivity and sugar yield than under NTC. The sugarcane variables did not differ between the managements.
\end{abstract}

(1) Part of the Doctoral Thesis of the first author at State University of Campinas. Fellow CNPq. Received for publication on October 8, 2012 and approved on September 12, 2013.

(2) Researcher, Espírito Santo State Institute of Research, Technical Assistance and Rural Extension (CRDR-CN/INCAPER). BR 101 North, km 151, Post Office Box 62, CEP 29915-140 Linhares (ES), Brazil. E-mail: gustavo.souza@incaper.es.gov.br

(3) Professor. University of Campinas (FEAGRI/UNICAMP). Cândido Rondon Avenue, 501, CEP 13083-875 Campinas (SP), Brazil. E-mail: zigomarms@feagri.unicamp.br

(4) Professor, Universidade Estadual Paulista "Júlio de Mesquita Filho" - UNESP, Unidade de Registro. Av. Nelson Brihi Badur, 430, Tupy Village. CEP 11900-000 Registro (SP), Brazil. E-mail: rbsilva@registro.unesp.br

(5) Doctorate in Agronomy, São Paulo State University - FCAV/UNESP, Campus de Jaboticabal. Via de Acesso Prof. Paulo Donato Castellani, s/n. CEP 14870-900 Jaboticabal (SP), Brazil. E-mail: rsbagronomo@gmail.com

(6) Professor. Federal University of Piauí (UFPI). Joaquim Nogueira de Oliveira Avenue, s/n, CEP 64980-000 Corrente (PI), Brazil. E-mail: fernandoaraujo@uespi.br 
The soil physical quality in the plant row was preserved under management TC1 and TC2, with an improved root development and increases of 18.72 and $20.29 \%$ in productivity and sugar yield, respectively.

Index terms: agricultural mechanization, soil compaction, root system, technological variables, Saccharum sp.

\title{
RESUMO: CONTROLE DE TRÁFEGO E SEU EFEITO NA QUALIDADE FÍSICA DO SOLO E NO CULTIVO DA CANA-DE-AÇÚCAR
}

\begin{abstract}
O cultivo do canavial com uso intenso de máquinas, principalmente na colheita, resulta na compactação do solo, o que influencia no desenvolvimento da cultura. O manejo com controle de tráfego agrícola representa uma alternativa ao setor, podendo preservar a qualidade física do solo, resultando em maior crescimento radicular, produtividade e qualidade da cana. Objetivou-se com este trabalho avaliar a qualidade fisica de um Latossolo Vermelho com e sem controle de tráfego agrícola e seu efeito no desenvolvimento radicular, na produtividade e na qualidade tecnológica da cana-de-açúcar. Os manejos avaliados foram: testemunha sem controle de tráfego (NTC), controle de tráfego com ajuste da bitola do trator e do transbordo de cana colhida (TC1) e controle de tráfego com ajuste da bitola e uso de piloto automático (TC2). Amostras de solo foram coletadas nas camadas 0,00-0,10; 0,10-0,20; e 0,20-0,30 m nas linhas de plantio e do rodado (entrelinha) e na região do canteiro, distante 0,30 $\mathrm{m}$ da linha de plantio. A produtividade foi medida com balança específica para transbordo. As variáveis tecnológicas da cana foram medidas em cada parcela. Os monólitos de solo foram coletados para análise do sistema radicular. O TC2 apresentou menor densidade e grau de compactação e maior porosidade total e macroporosidade na linha de plantio. A resistência do solo à penetração, na linha de plantio, foi inferior a 2 MPa no TC1 e no TC2. Os sistemas de manejo não diferiram quanto à agregação do solo e ao carbono orgânico total. Os manejos TC1 e TC2 apresentaram maior superfície e volume radicular, com maior produtividade e rendimento de açúcar em relação ao manejo NTC. As variáveis tecnológicas da cana não diferiram entre os manejos. Os manejos TC1 e TC2 preservaram a qualidade física do solo na região da soqueira, aumentando o desenvolvimento radicular, com incremento de 18,72 e 20,29\% na produtividade de cana e no rendimento de açúcar, respectivamente.
\end{abstract}

Termos de indexação: mecanização agrícola, compactação do solo, sistema radicular, qualidade tecnológica, Saccharum sp.

\section{INTRODUCTION}

Sugarcane is a key crop in the current scenario of the Brazilian agriculture, economically one of the most important, with prospects for expansion of the crop in the next years. One possibility of improving the profitability of the sugarcane production system is the use of mechanical harvesting without burning, which is a worldwide acknowledged, rational management technique, which triggers a series of environmental and economic benefits.

In the production system of harvested sugarcane without burning, agricultural machinery is used in all activities related to tillage, cultural practices, and harvest. This causes heavy tractor traffic on the soil, leading to a low efficiency of the machinery, high operational costs and mainly to soil compaction. The reason is that the traditional management system uses a spacing of 1.4-1.5 m and a track width of the vehicles of less than 2.0 $\mathrm{m}$, i.e., the machinery pass over the plant stumps, which can reduce the productivity and longevity of sugarcane fields (Souza et al., 2005; Braunack \& McGarry, 2006).

Research has shown the effect of compaction on the soil physical quality, increasing soil density and mechanical strength (Materechera, 2009; Cavalieri et al., 2011) and decreasing the pore volume, particularly of macropores (Streck et al., 2004; Souza et al., 2006; Braunack \& McGarry, 2006). Soil compaction also affects the soil structure, changing the aggregate stability and modifying the particle arrangement (Tullberg et al., 2007; Roque et al., 2010; Vezzani \& Mielniczuk, 2011). These changes create a less favorable environment for the development of the cane root system (Alvarez et al., 2000; Otto et al., 2009, 2011), reducing the productivity (Paulino et al., 2004; Braunack \& McGarry, 2006). Agricultural managers are concerned about the restrictions in the soil for root development in sugarcane fields, for hampering the commercial production (Smith et al., 2005)

Studies have also shown the effect of agricultural management on the quality of the raw material of 
sugarcane (Wiedenfeld, 2008; Larrahondo et al., 2009). Improvements in soil properties can also contribute to increase the sugarcane quantity and quality (Meyer \& Wood, 2001; Souza et al., 2005; Braunack \& McGarry, 2006). In the sugarcane industry, the commercial value of cane is based on the quality of the raw material, measured by technological variables (Meyer \& Wood, 2001; Consecana, 2006). Thus, improving the sugarcane quality in the phases of the agricultural production process improves the competitiveness of the company on the domestic and international markets (Larrahondo et al., 2009). However, there are few studies in the literature focused on the soil physical quality and its effects on the technological variables of sugarcane.

A solution to decrease the effect of soil compaction by agricultural machinery traffic on the crop development is the adoption of a system of controlled traffic or agricultural traffic control (Tullberg et al., 2007; Materechera, 2009). In this system, the field consists of zones used exclusively for traffic and others exclusively for plant growth, concentrating the passing of the tires along defined tracks, so a smaller area is affected, though more intensely (Braunack \& McGarry, 2006; Vermeulen \& Mosquera, 2009). The traffic zones can remain in the same place for one crop cycle or be maintained over several cycles, as commonly done for sugarcane. There is still a need to validate a traffic control management adapted to the growing conditions of Brazilian sugarcane fields that would fit the peculiarities of this heavily mechanized production system.

The use of the management with traffic control in agricultural areas that preserve the physical soil quality in the growing region of the root system, resulting in improvements in soil physical quality and contributing to the sustainability of crops (McHugh et al., 2009; Qingjie et al., 2009). This improvement in soil physical quality is associated with a reduction in the trafficked area (Laguë et al., 2003). Another advantage is the practicality and economic viability of this promising innovative technology for agricultural production systems, since it can increase profits by up to $50 \%$ (Tullberg et al., 2007; Kingwell \& Fuchsbichler, 2011).

Another technique of increasing importance in the agricultural sector that can be used together with the traffic control is the assisted steering system, popularly known as autopilot. The autopilot corrects the lateral alignment of the agricultural machinery and allows a displacement with minor deviations from the central alignment along a straight or curved course. In crops that cover large areas, such as sugarcane, the parallelism between rows promotes greater efficiency in traffic, since the implements have constant width, avoiding tractor wheel traffic on the crop row, which affects the aerial part and root system (Braunack \& McGarry, 2006; Vermeulen \& Mosquera, 2009).
Therefore, it is possible that the traffic control, consisting of the adjustment of the vehicle track width and use of an autopilot, reduces soil compaction in the plant rows, improving the root development, productivity and technological variables of sugarcane. Thus, the purpose of this study was to evaluate the physical quality of an Oxisol under managements with and without traffic control and their effects on the root development, productivity and technological variables of sugarcane.

\section{MATERIAL AND METHODS}

The experiment was conducted in a commercial sugarcane field (Saccharum sp.) in Pradópolis, State of São Paulo (latitude 21 $18^{\prime} 67^{\prime \prime} \mathrm{S}$ and $48^{\circ} 11^{\prime} 38^{\prime \prime} \mathrm{W}$; $630 \mathrm{~m}$ asl). The area has a history of intensive sugarcane cultivation for over 30 consecutive years, in the last 12 years without burning at harvest. The climate is mesothermal with dry winters (Cwa), according to the Köppen classification, with an average annual rainfall of $1,400 \mathrm{~mm}$, concentrated between November and February.

The experiment was carried out on a 16.20 ha field with undulated relief. The soil was classified as a Latossolo Vermelho distrófico típico (LVd), with a moderate clayey horizon (Embrapa, 2006) and Oxisol - Typic Kandiudox (Soil Survey Staff, 2010) (Table 1). The sugarcane variety RB855453 was planted on August 29, 2007, being harvested for the third time in the experimental period in 2010. The following management systems were installed: no traffic control (NTC), with spacing between plant rows of $1.5 \mathrm{~m}$ and a track width of the tractor and sugarcane trailer (loading truck of harvested cane) of $2.0 \mathrm{~m}$; traffic control (TC1) with plant row spacing of $1.5 \mathrm{~m}$ and adjustment of track width of tractor and trailer to $3.0 \mathrm{~m}$ and traffic control (TC2) with plant row spacing of $1.5 \mathrm{~m}$ and adjustment of track width of tractor and trailer to $3.0 \mathrm{~m}$ and use of an autopilot at planting and the subsequent harvests. The adjustment of the track width of the tractor and sugarcane trailer alters the area directly in contact with the tires due to the overlapping of the vehicle tracks. In the systems with and without traffic control, 47 and $73 \%$ of the total cultivation area were driven over by the tires of the tractor and sugarcane trailer, respectively. In all three management systems, the area impacted by the harvester was $56 \%$. The adoption of traffic control resulted in the coining of the term "sugarcane seedbed region", which is the soil strip of at least $0.40 \mathrm{~m}$ width on either side of the plant row that is untouched by the traffic tires of the tractor and sugarcane trailer, which is concentrated in the center of the inter-rows.

The experimental area was prepared by the mechanical removal of ratoon sugarcane of the previous crop and subsoiling to $0.45 \mathrm{~m}$, in the planting rows 
only, on July 15, 2007. Before soil tilling $2.5 \mathrm{Mg} \mathrm{ha}^{-1}$ limestone was applied and $20 \mathrm{Mg} \mathrm{ha}^{-1}$ filter cake at planting. In July 2009 and 2010, after harvest, 280 and $260 \mathrm{~kg} \mathrm{ha}^{-1}$ of N-P-K fertilizer (32-00-02) were applied, respectively, and $100 \mathrm{~m}^{3} \mathrm{ha}^{-1}$ of vinasse. For the mechanical operations, the tractor model CaseIH Magnum was used, with all-wheel-drive, maximum engine power of $270 \mathrm{HP}(198 \mathrm{~kW})$, mass of 11.7 Mg, Trelleborg TM900 tires (600-70 R30 in front and 650-85 R38 rear tires), with a tire pressure of $110 \mathrm{kPa}$ and 150 , respectively, to pull the implements. At harvest on June 10, 2010, a track harvester series A-7700 Case IH was used, track width $1.88 \mathrm{~m}$, on caterpillar tracks, maximum engine power of $335 \mathrm{HP}$ $(246 \mathrm{~kW})$ and mass of $18.5 \mathrm{Mg}$ and a tractor Case-IH, pulling a loading truck with three compartments, with average total mass of $40 \mathrm{Mg}$ and Trelleborg tires Twin404 600-50 R22, 5 with inflation pressure of $110 \mathrm{kPa}$.

Disturbed and undisturbed soil was sampled from the three treatments under the plant row (PR), the inter-row center (IRC) and the seedbed region (SB), at a distance of $0.30 \mathrm{~m}$ from the plant row. For this purpose, trenches $(0.90 \times 0.40 \times 0.40 \mathrm{~m})$ were opened, perpendicular to the PR direction. Disturbed and undisturbed soil was sampled from the center of the layers $0.00-0.10,0.10-0.20$ and $0.20-0.30 \mathrm{~m}$ to determine the physical properties. Undisturbed soil was collected in volumetric cylinders (diameter $0.05 \mathrm{~m}$, height $0.05 \mathrm{~m}$ ) to measure bulk density $(\mathrm{Bd})$ and total porosity. The microporosity was determined by subjecting the cylinders to a voltage of $6.0 \mathrm{kPa}$ after soil saturation and macroporosity was measured by the difference between the total porosity and microporosity (Embrapa, 1997). The compaction degree was assessed by the relationship between $\mathrm{Bd}$ and maximum density, identified by standard proctor test (Carter, 1990; Reichert et al., 2009). The compaction curve obtained by the standard proctor test $\left(\mathrm{Bd}=-0.90^{* *}+14.66^{* *} \mathrm{x}-23.39^{* * *} \mathrm{x}^{2}\right.$, $\mathrm{R}^{2}=0.96^{* *}, \mathrm{n}=7$ ), indicated a maximum soil density of $1.40 \mathrm{Mg} \mathrm{m}^{-3}$ related to the optimum moisture content of $0.31 \mathrm{~kg} \mathrm{~kg}^{-1}$.

The soil penetration resistance was determined by an impact penetrometer with a cone angle of $30^{\circ}$. The soil penetration at the rod of the device (cm/impact) was transformed into soil penetration resistance as described by Stolf (1991). The soil water content was determined by the gravimetric method (Embrapa,
1997). The penetration resistance and water content were determined at the same points and layers as of soil sampling.

Undisturbed soil samples were manually removed for analysis of the aggregate stability and soil organic matter and packed in plastic containers. The aggregate stability was measured by wet-sieving (Kemper \& Chepil, 1965). The aggregates were obtained by manual manipulation of the soil clods. Aggregates with a diameter of 2.00 to $6.35 \mathrm{~mm}$ were separated by wet-sieving, using sieves of $2.0,1.0,0.5$ and $0.125 \mathrm{~mm}$ mesh. The aggregate mass in the different sieve classes was calculated. The following aggregation indices were used: mean weight-diameter, calculated as the mean sieve diameter weighted by the soil mass; stable aggregates, as the percentage of aggregates with a diameter $>2.0 \mathrm{~mm}$, and aggregate stability index, which is the percentage of aggregates with a diameter $>0.125 \mathrm{~mm}$ (Wendling et al., 2005).

The crop was harvested mechanically without burning on June 10, 2010, by a self-propelled harvester, accompanied by a tractor and sugarcane trailer. The sugarcane trailer was weighed empty and full, immediately after the harvest of each plot to determine the productivity, using a specific weighing scale. Each plot consisted of 14 plant rows with a length of $50 \mathrm{~m}$. At harvest, 10 sugarcane stalks in sequence were collected from the center row of each plot to determine the technological variables: cane fiber, brix (total soluble solids) in cane juice, cane juice purity, apparent sucrose content and total recoverable sugar (Consecana, 2006). The sugar yield was calculated as the product of productivity and total recoverable sugar.

Immediately after harvest, samples were collected from each plot for analysis of the root system. In each plot one trench was opened perpendicular to the plant rows and between two plant rows to collect 18 monoliths (width 0.25 , height 0.10 , length $0.10 \mathrm{~m}$ ), according to Vasconcelos et al. (2003) and Otto et al. (2009, 2011). The monoliths were collected with a stainless steel box, with openings in the top and bottom, which was driven into the soil in the trench wall at the same points and layers used for soil sampling. Roots were separated from the soil by washing in water and sieving $(2.0 \mathrm{~mm})$ (Vasconcelos et al., 2003). The root images were scanned in an optical scanner (resolution $400 \mathrm{dpi}$ ) to analyze root diameter, density, surface area and volume using

Table 1. Characterization chemical and granulometry of an Oxisol

\begin{tabular}{|c|c|c|c|c|c|c|c|c|c|c|c|c|}
\hline Soil layer & $\mathrm{pH}^{(1)}$ & $\mathbf{P}$ & $\mathbf{K}$ & $\mathbf{C a}$ & $\mathrm{Mg}$ & $\mathrm{H}+\mathrm{Al}$ & SB & CTC & $\mathrm{V}$ & Clay $^{(2)}$ & Silt & Sand \\
\hline $\mathrm{m}$ & & $\mathrm{mg} \mathrm{dm} \mathrm{m}^{-3}$ & & 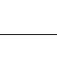 & - & $\mathrm{ol}_{\mathrm{c}} \mathrm{dm}^{-3}$ & & & $\%$ & & $\mathrm{~g} \mathrm{~kg}^{-1}$ & \\
\hline $0.00-0.10$ & 5.4 & 163 & 12 & 64 & 30 & 42 & 106 & 149 & 72 & 534 & 310 & 156 \\
\hline $0.10-0.20$ & 4.8 & 45 & 8 & 24 & 14 & 47 & 46 & 93 & 49 & 555 & 298 & 147 \\
\hline $0.20-0.30$ & 4.9 & 71 & 9 & 32 & 18 & 52 & 59 & 111 & 53 & 581 & 288 & 131 \\
\hline
\end{tabular}

(1) Raij et al. (2001); (2) Pipette method at low rotation (Camargo et al., 1986). 
software SAFIRA ${ }^{\circledR}$. The roots were dried in a forcedair oven at $65^{\circ} \mathrm{C}$ to constant weight, to determine dry matter (Otto et al., 2009, 2011).

The experiment was arranged in a randomized block design $(n=4)$, with three management systems distributed in 12 plots, for analysis of productivity and technological variables. For the data analysis of the soil properties and root system, the same design was considered, with a split-plot arrangement [management system $(n=3)$, sampling site $(n=3)$, soil layer $(\mathrm{n}=3)$ ], totaling 108 observations. In each plot, three trenches were opened (replication) to collect soil samples $(n=324)$; roots were collected only from the central trench in duplicate $(n=216)$. Statistical analysis was performed using the SAS program (SAS, $2008)$, by analysis of variance $(p<0.05)$. In case of significance for interactions or between levels of the isolated factors, the Tukey test was applied $(p<0.05)$.

\section{RESULTS AND DISCUSSION}

Analysis of variance was not significant $(p<0.05)$ for the properties of soil and those related to root development for the triple interactions (management system $\times$ sampling site $\times$ soil layer), but the double interactions were statistically significant (management $\times$ sampling site and/or management $\times$ soil layer). When the double interactions were not significant by the $\mathrm{F}$ test, the factor levels were analyzed separately.

Higher total porosity and macroporosity in the plant row were observed in the managements $\mathrm{TC} 1$ and TC2 and lower soil $\mathrm{Bd}$ and compaction degree under TC2 than NTC, also in the plant row (Table 2). This was due to the absence of traffic of tires of the tractor and trailer over or near the plant rows under TC1 and TC2, owing to the adjustment of the track width, with or without the use of an autopilot. These results are in agreement with Qingjie et al. (2009), which indicated that the management with control of agricultural traffic was efficient in improving soil physical conditions in China. McHugh et al. (2009) also observed a reduced $\mathrm{Bd}$ of 1.40 to $1.25 \mathrm{Mg} \mathrm{m}^{-3}$ in the crop row after 22 months of implementation of the traffic control after 30 years of conventional management.

The soil physical properties under the inter-row center and the region of the seedbed did not differ significantly between the treatments, with the exception of TC2, where total porosity was lowest under the inter-row center (Table 2). The use of an autopilot in management TC2 shifts the position of the vehicle tires into the middle of the sugarcane interrow - which are permanent traffic lines - increasing the compaction. This higher compaction was a result of stress distribution in the soil due to the traffic that occurred throughout the three cycles of sugarcane cultivation with traffic control. However, a higher soil compaction in the vehicle tracks improves traffic conditions and increases the traction efficiency (Laguë et al., 2003; Kingwell \& Fuchsbichler, 2011). This scenario is beneficial to the agricultural activity, improving soil conditions for crop growth and for machinery traffic.

Under TC1 and TC2, there was an increase in total porosity and macroporosity in the direction of the interrow center to the plant row (Table 2). This behavior was not observed for management NTC, due to tire traffic on the seedbed and/or plant row, while the impacted area under TC1 and TC2 was smaller, agreeing with Laguë et al. (2003) and Braunack \& McGarry (2006). In the traffic-free areas, soil conditions are ideal for sugarcane development, since there is no obstacle to the development of the root system, influencing the productivity and longevity of the sugarcane field positively (Braunack \& McGarry, 2006).

The $\mathrm{Bd}$, compaction degree and soil penetration resistance decreased from IRC $>\mathrm{SB}>\mathrm{PR}$ for $\mathrm{TC} 2$, which did not occur in the management systems TC1 and NTC, where the values were similar under the interrow center and seedbed. The use of an autopilot in TC2 reduced errors in parallelism of traffic of agricultural machinery, avoiding tractor and trailer traffic on the plant rows (Vermeulen \& Mosquera, 2009), which resulted in this variation in soil physical properties from the inter-row center to the plant row. The soil water content (data not shown) did not differ significantly between management systems, with an average value in the plots of $0.176 \mathrm{~kg} \mathrm{~kg}^{-1}$. Soil penetration resistance is a property influenced by the soil water content and given the horizontal and vertical uniformity of the soil water content during the sampling period, the apparent effect on penetration resistance must be associated with differences caused by the soil management.

Soil Bd ranged from 1.10 to $1.17 \mathrm{Mg} \mathrm{m}^{-3}$ in the plant row and 1.30 to $1.35 \mathrm{Mg} \mathrm{m}^{-3}$ in the interrow center (Table 2 ). These density values agreed with Neves et al. (2003), who observed a density of $1.42 \mathrm{Mg} \mathrm{m}^{-3}$ in compacted areas and $1.18 \mathrm{Mg} \mathrm{m}^{-3}$ in uncompacted areas in Latossolos Vermelhos distroférricos with clay contents of approximately $700 \mathrm{~g} \mathrm{~kg}^{-1}$. Otto et al. (2009) observed a soil Bd of 1.46 to $1.64 \mathrm{Mg} \mathrm{m}^{-3}$ in a Latossolo Vermelho with medium texture. The average compaction degree in the treatments ranged from 78.6 to $96.2 \%$, in agreement with Carter (1990) and Reichert et al. (2009).

The average total porosity was 0.535 and $0.572 \mathrm{~m}^{3} \mathrm{~m}^{-3}$, in the inter-rows and plant rows, respectively. These results agreed with Neves et al. (2003), who also observed a total porosity of $0.48 \mathrm{~m}^{3} \mathrm{~m}^{-3}$ in compacted areas and $0.60 \mathrm{~m}^{3} \mathrm{~m}^{-3}$ in uncompacted areas. Otto et al. (2011) reported a total porosity of 0.39 and $0.49 \mathrm{~m}^{3} \mathrm{~m}^{-3}$ in vehicle tracks and plant rows in a Latossolo Vermelho with 
Table 2. Physical properties of an Oxisol measured in the plant row (PR), inter-row center (IRC) and seedbed (SB) in the studied layers under managements with traffic control consisting of the adjustment of the track width and use of an autopilot (TC2) and only adjusted track width (TC1) and no traffic control (NTC)

\begin{tabular}{|c|c|c|c|c|c|c|c|}
\hline \multirow{2}{*}{ Management system } & \multicolumn{3}{|c|}{ Sampling site } & \multicolumn{4}{|c|}{ Soil layer } \\
\hline & IRC & SB & $\mathbf{P R}$ & $0.00-0.10 \mathrm{~m}$ & $0.10-0.20 \mathrm{~m}$ & $0.20-0.30 \mathrm{~m}$ & Mean \\
\hline & \multicolumn{7}{|c|}{ Bulk density $\left(\mathrm{Mg} \mathrm{m}^{-3}\right)$} \\
\hline $\mathrm{TC} 2$ & $1.35 \mathrm{Aa}$ & $1.23 \mathrm{Ab}$ & $1.10 \mathrm{Bc}$ & 1.24 & 1.21 & 1.22 & $1.23 \mathrm{~A}$ \\
\hline $\mathrm{TC} 1$ & $1.32 \mathrm{Aa}$ & $1.27 \mathrm{Aa}$ & $1.16 \mathrm{Ab}$ & 1.27 & 1.25 & 1.23 & $1.24 \mathrm{~A}$ \\
\hline NTC & $1.30 \mathrm{Aa}$ & $1.29 \mathrm{Aa}$ & $1.17 \mathrm{Ab}$ & 1.26 & 1.25 & 1.26 & $1.25 \mathrm{~A}$ \\
\hline Mean & 1.32 & 1.26 & 1.14 & $1.26 \mathrm{a}$ & $1.24 \mathrm{a}$ & $1.24 \mathrm{a}$ & \\
\hline \multirow[t]{2}{*}{ CV (\%) } & 2.41 & & & & & & \\
\hline & \multicolumn{7}{|c|}{ Compaction degree (\%) } \\
\hline TC2 & $96.2 \mathrm{Aa}$ & $87.8 \mathrm{Ab}$ & $78.6 \mathrm{Bc}$ & 88.6 & 86.8 & 87.2 & $87.5 \mathrm{~A}$ \\
\hline $\mathrm{TC} 1$ & $94.2 \mathrm{Aa}$ & $90.8 \mathrm{Aa}$ & $82.6 \mathrm{ABb}$ & 90.8 & 89.4 & 87.8 & $88.1 \mathrm{~A}$ \\
\hline NTC & $92.8 \mathrm{Aa}$ & $92.0 \mathrm{Aa}$ & $83.7 \mathrm{Ab}$ & 89.8 & 89.1 & 89.9 & $89.6 \mathrm{~A}$ \\
\hline Mean & 94.4 & 90.1 & 81.6 & $90.0 \mathrm{a}$ & $88.5 \mathrm{a}$ & $88.4 \mathrm{a}$ & \\
\hline \multirow[t]{2}{*}{$\mathrm{CV}(\%)$} & 3.47 & & & & & & \\
\hline & \multicolumn{7}{|c|}{ Total porosity $\left(\mathrm{m}^{3} \mathrm{~m}^{-3}\right)$} \\
\hline $\mathrm{TC} 2$ & $0.520 \mathrm{Bc}$ & $0.557 \mathrm{Ab}$ & $0.584 \mathrm{Aa}$ & 0.548 & 0.557 & 0.557 & $0.554 \mathrm{~A}$ \\
\hline TC1 & $0.547 \mathrm{Ab}$ & $0.549 \mathrm{Ab}$ & $0.576 \mathrm{Aa}$ & 0.556 & 0.558 & 0.558 & $0.557 \mathrm{~A}$ \\
\hline NTC & $0.540 \mathrm{Aa}$ & $0.542 \mathrm{Aa}$ & $0.556 \mathrm{Ba}$ & 0.539 & 0.553 & 0.546 & $0.546 \mathrm{~A}$ \\
\hline Mean & 0.535 & 0.550 & 0.572 & $0.548 \mathrm{a}$ & $0.556 \mathrm{a}$ & $0.554 \mathrm{a}$ & \\
\hline \multirow[t]{2}{*}{$\mathrm{CV}(\%)$} & 2.92 & & & & & & \\
\hline & \multicolumn{7}{|c|}{ Macroporosity $\left(\mathrm{m}^{3} \mathrm{~m}^{-3}\right)$} \\
\hline $\mathrm{TC} 2$ & $0.167 \mathrm{Ab}$ & $0.176 \mathrm{Ab}$ & $0.196 \mathrm{Aa}$ & 0.177 & 0.185 & 0.177 & $0.179 \mathrm{~A}$ \\
\hline TC1 & $0.180 \mathrm{Ab}$ & $0.193 \mathrm{Aab}$ & $0.206 \mathrm{Aa}$ & 0.191 & 0.192 & 0.196 & $0.193 \mathrm{~A}$ \\
\hline NTC & $0.184 \mathrm{Aa}$ & $0.178 \mathrm{Aa}$ & $0.174 \mathrm{Ba}$ & 0.173 & 0.183 & 0.181 & $0.179 \mathrm{~A}$ \\
\hline Mean & 0.177 & 0.182 & 0.193 & $0.180 \mathrm{a}$ & $0.186 \mathrm{a}$ & $0.184 \mathrm{a}$ & \\
\hline \multirow[t]{2}{*}{ CV (\%) } & 8.79 & & & & & & \\
\hline & \multicolumn{7}{|c|}{ Microporosity $\left(\mathrm{m}^{3} \mathrm{~m}^{-3}\right)$} \\
\hline $\mathrm{TC} 2$ & $0.355 \mathrm{Ab}$ & $0.387 \mathrm{Aa}$ & $0.401 \mathrm{Aa}$ & 0.397 & 0.377 & 0.368 & $0.381 \mathrm{~A}$ \\
\hline $\mathrm{TC} 1$ & $0.352 \mathrm{Aa}$ & $0.357 \mathrm{Aa}$ & $0.367 \mathrm{Aa}$ & 0.362 & 0.363 & 0.352 & $0.359 \mathrm{~A}$ \\
\hline NTC & $0.357 \mathrm{Ab}$ & $0.361 \mathrm{Ab}$ & $0.398 \mathrm{Aa}$ & 0.388 & 0.368 & 0.360 & $0.372 \mathrm{~A}$ \\
\hline Mean & 0.355 & 0.369 & 0.389 & $0.383 \mathrm{a}$ & $0.370 \mathrm{~b}$ & $0.360 \mathrm{~b}$ & \\
\hline \multirow[t]{2}{*}{ CV (\%) } & 5.58 & & & & & & \\
\hline & \multicolumn{7}{|c|}{ Soil penetration resistance $(\mathrm{MPa})$} \\
\hline $\mathrm{TC} 2$ & $8.31 \mathrm{Aa}$ & $4.75 \mathrm{Ab}$ & $1.69 \mathrm{Ac}$ & 5.34 & 5.09 & 4.32 & $4.92 \mathrm{~A}$ \\
\hline $\mathrm{TC} 1$ & $7.19 \mathrm{Aa}$ & $5.11 \mathrm{Aa}$ & $1.62 \mathrm{Ab}$ & 5.12 & 4.88 & 3.91 & $4.64 \mathrm{~A}$ \\
\hline NTC & $6.49 \mathrm{Aa}$ & $7.01 \mathrm{Aa}$ & $2.54 \mathrm{Ab}$ & 6.25 & 5.32 & 4.47 & $5.34 \mathrm{~A}$ \\
\hline Mean & 7.33 & 5.62 & 1.95 & $5.57 \mathrm{a}$ & $5.10 \mathrm{~b}$ & $4.24 \mathrm{c}$ & \\
\hline CV (\%) & 16.42 & & & & & & \\
\hline
\end{tabular}

Means followed by the same capital letter in the column and lowercase in the line did not differ statistically $(p<0.05)$.

approximately $300 \mathrm{~g} \mathrm{~kg}^{-1}$ clay. In the management systems, sampling sites and soil layers, the macroporosity was greater than $0.10 \mathrm{~m}^{3} \mathrm{~m}^{-3}$ (Table 2), which is considered a minimum threshold for soil aeration of macropores, required for the development of the root system (Xu et al., 1992). This indicates a probable absence of limitations to soil aeration, even in periods of heavy rainfall. The average microporosity ranged from 0.355 to $0.389 \mathrm{~m}^{3} \mathrm{~m}^{-3}$ at the sampling sites, following the changes in macroporosity and total porosity, which disagrees with Streck et al. (2004). Paulino et al. (2004) found microporosity ranging from 0.273 to $0.320 \mathrm{~m}^{3} \mathrm{~m}^{-3}$, respectively, in a scarified and harrowed Latossolo Vermelho with $260 \mathrm{~g} \mathrm{~kg}^{-1}$ clay.

In the plant row, values of soil penetration resistance ranged from 1.62 to $2.54 \mathrm{MPa}$ (Table 2). Similar values were observed by Souza et al. (2006) and Roque et al. (2010) in soils cultivated with 
sugarcane. Penetration resistance only reached a level considered restrictive to root growth $(>2 \mathrm{MPa})$ (Otto et al., 2011) in the plant row in the management NTC, indicating the soil physical degradation. Considering the trend of using reduced tillage at sugarcane planting, the lower penetration resistance in the plant row reduces the energy consumption and wear of implements and improves the efficiency of agricultural machinery for soil tillage, since the active parts (furrowers) will work in a traffic-free area (Laguë et al., 2003; Kingwell \& Fuchsbichler, 2011).

There was no difference in Bd, compaction degree, total porosity, and macroporosity between the evaluated soil layers, although microporosity and penetration resistance decreased in the deeper layers of the three management systems (Table 2). Thus, the increased penetration resistance at the surface reduced macroporosity and increase the proportion of micropores. In sugarcane cultivation, soil disturbance occurs at crop replanting, usually every five years, so that the traffic effect is accumulated mainly at the surface (Cavalieri et al., 2011). It is noteworthy that, in the traffic control, the soil remains compacted by machinery in the crop inter-row center, which does not limit the root growth (Otto et al., 2009) and can increase the longevity of sugarcane.

The management systems did not differ in mean weight-diameter, stable aggregates and aggregate stability index (Table 3). These results agreed with Roque et al. (2010), whereas Braunack \& McGarry (2006) found differences in the stability of soil aggregates of the seedbed region in sugarcane fields under different tillage systems. The agricultural machinery traffic can cause compaction of the soil aggregates, leading to aggregate rupture and the formation of a massive soil structure, however, the wet sieving process is not able to distinguish stable aggregates from massive soil structures, showing no significant difference between the results for the respective management systems (Severiano et al., 2008). The indices of soil aggregation were less sensitive to changes in management than soil $\mathrm{Bd}$ and porosity.

In all management systems, the mean aggregation was greater in the plant row than in the seedbed region and inter-row center, which may be explained by the values of total organic carbon (Table 3 ). The results indicated the preservation of structural quality in the plant row, which is beneficial to the development of sugarcane roots. The highest content of total organic carbon in PR is related to the greater root development and the concentrated application of filter cake there. These results agree with the higher aggregation levels in the plant row, since organic matter is a major cementing agent, responsible for the formation and stabilization of aggregates (Vezzani \& Mielniczuk, 2011). The sugarcane root system also contributes to soil aggregation by the mechanical action of the roots and the excretion of substances with aggregating action (Wendling et al., 2005; Vezzani \& Mielniczuk, 2011).
For the management systems, the mean weightdiameter, stable aggregates and aggregate stability index differed with soil depth; the values were highest in the 0.00-0.10 m layer and decreased in deeper layers (Table 3). Total organic carbon also decreased with depth, which again justifies the reduction of soil aggregation indices in deeper layers. These results corroborate Wendling et al. (2005) and Roque et al. (2010).

The root surface and volume did not differ between management systems with traffic control (Table 4). In TC2, the surface area and root volume were greater in the seedbed region and the plant row, due to less soil compaction. Paulino et al. (2004) also observed an increased surface area and density of sugarcane roots with the increase of macroporosity and reduced $\mathrm{Bd}$. The increased surface area and root volume favors the development of the aerial part of the crop, since explore a greater soil volume can be explored, and from the greater area of soil-root contact, absorb more water and nutrients. This improved soil exploitation is important, especially for nutrients with low soil mobility, such as P (Smith et al., 2005).

The management systems differ for root dry matter (RDM), with highest values in TC2 in the three soil layers (Table 4). These results are associated to improvements in soil physical quality promoted by adjusting the track width and use of an autopilot, corroborating Otto et al. (2009, 2011). The RDM decreased when soil compaction exceeded $86 \%$, corresponding to a $\mathrm{Bd}$ of $1.20 \mathrm{Mg} \mathrm{m}^{-3}$, and above $93 \%$ $\left(\mathrm{Bd} 1.30 \mathrm{mg} \mathrm{m}^{-3}\right)$ the soil physical restrictions were more severe for root development (Figure 1). The values of RDM were lower than those reported by Vasconcelos et al. (2003) in a sugarcane field harvested mechanically (1.33 $\left.\mathrm{g} \mathrm{dm}^{-3}\right)$, eight months after planting (layer 0.00-0.20 m) in the fifth crop cycle, in São Paulo state. Aside from the effects of variety, soil fertility management and climate, the sampling time may have influenced the results, since the roots were sampled immediately after sugarcane harvest, in a period of sugarcane senescence (Smith et al., 2005).

The RDM and density increased in the direction $\mathrm{IRC}<\mathrm{SB}<\mathrm{PR}$ for $\mathrm{TC} 2$, however in the managements TC1 and NTC, the values did not differ between the sampling sites (Table 4). Braunack \& McGarry (2006) and Otto et al. (2009) also observed a reduction in the development of the sugarcane root system with increasing distances from the plant row and approaching the inter-row center, due to higher soil compaction. Plant responses to soil compaction are mediated by changes in the development and functioning of roots (Alameda et al., 2012), which can affect productivity and product quality.

In the three management systems, RDM and surface decreased in the deeper layers (Table 4). This was due to decreasing soil structure and nutrient availability with depth (Table 1). According to Smith et al. (2005), the concentration of sugarcane RDM and 
Table 3. Aggregate stability of an Oxisol measured in the plant row (PR), inter-row center (IRC) and seedbed (SB) in the layers in study under managements with traffic control consisting of the adjustment of the track width and use of an autopilot (TC2) and only adjusted track width (TC1) and no traffic control (NTC)

\begin{tabular}{|c|c|c|c|c|c|c|c|}
\hline \multirow{2}{*}{ Management system } & \multicolumn{3}{|c|}{ Sampling site } & \multicolumn{4}{|c|}{ Soil layer } \\
\hline & IRC & SB & PR & $0.00-0.10 \mathrm{~m}$ & $0.10-0.20 \mathrm{~m}$ & $0.20-0.30 \mathrm{~m}$ & Mean \\
\hline & \multicolumn{7}{|c|}{ Mean weight diameter (mm) } \\
\hline $\mathrm{TC} 2$ & 2.53 & 2.60 & 2.95 & 3.07 & 2.67 & 2.34 & $2.69 \mathrm{~A}$ \\
\hline $\mathrm{TC} 1$ & 2.62 & 2.72 & 3.12 & 3.01 & 2.95 & 2.51 & $2.82 \mathrm{~A}$ \\
\hline NTC & 2.32 & 2.56 & 3.07 & 3.07 & 2.68 & 2.21 & $2.65 \mathrm{~A}$ \\
\hline Mean & $2.49 \mathrm{~b}$ & $2.63 \mathrm{~b}$ & $3.05 \mathrm{a}$ & $3.05 \mathrm{a}$ & $2.77 \mathrm{~b}$ & $2.35 \mathrm{c}$ & \\
\hline \multirow[t]{2}{*}{$\mathrm{CV}(\%)$} & 9.48 & & & & & & \\
\hline & \multicolumn{7}{|c|}{ Stable aggregates (\%) } \\
\hline $\mathrm{TC} 2$ & 51.07 & 52.95 & 62.83 & $66.50 \mathrm{Aa}$ & $54.81 \mathrm{Ab}$ & $45.53 \mathrm{Ab}$ & 55.61 \\
\hline $\mathrm{TC} 1$ & 53.34 & 56.15 & 68.12 & $64.66 \mathrm{Aa}$ & $62.83 \mathrm{Aa}$ & $50.12 \mathrm{Ab}$ & 59.20 \\
\hline NTC & 44.84 & 51.57 & 66.61 & $66.40 \mathrm{Aa}$ & $55.09 \mathrm{Ab}$ & $41.54 \mathrm{Ac}$ & 54.34 \\
\hline Mean & $49.75 \mathrm{~b}$ & $53.56 \mathrm{~b}$ & $65.85 \mathrm{a}$ & 65.85 & 57.58 & 45.73 & \\
\hline \multirow[t]{2}{*}{$\mathrm{CV}(\%)$} & 13.41 & & & & & & \\
\hline & \multicolumn{7}{|c|}{ Aggregate stability index (\%) } \\
\hline $\mathrm{TC} 2$ & 87.71 & 89.93 & 95.49 & 94.57 & 90.98 & 87.58 & $91.04 \mathrm{~A}$ \\
\hline $\mathrm{TC} 1$ & 87.53 & 89.71 & 94.05 & 94.31 & 91.40 & 85.57 & $90.43 \mathrm{~A}$ \\
\hline NTC & 86.56 & 89.40 & 91.43 & 94.17 & 89.60 & 83.61 & $89.13 \mathrm{~A}$ \\
\hline Mean & $87.26 \mathrm{c}$ & $89.68 \mathrm{~b}$ & $93.65 \mathrm{a}$ & $94.35 \mathrm{a}$ & $90.66 \mathrm{~b}$ & $85.59 \mathrm{c}$ & \\
\hline \multirow[t]{2}{*}{$\mathrm{CV}(\%)$} & 3.43 & & & & & & \\
\hline & \multicolumn{7}{|c|}{ Total organic carbon $\left(\mathrm{g} \mathrm{kg}^{-1}\right)$} \\
\hline $\mathrm{TC} 2$ & 2.15 & 2.52 & 2.61 & 2.85 & 2.42 & 2.00 & $2.43 \mathrm{~A}$ \\
\hline $\mathrm{TC} 1$ & 2.10 & 2.20 & 2.35 & 2.87 & 2.10 & 1.69 & $2.22 \mathrm{~A}$ \\
\hline NTC & 2.06 & 2.25 & 2.71 & 2.84 & 2.21 & 1.97 & $2.34 \mathrm{~A}$ \\
\hline Mean & $2.10 \mathrm{~b}$ & $2.32 \mathrm{ab}$ & $2.56 \mathrm{a}$ & $2.85 \mathrm{a}$ & $2.25 \mathrm{~b}$ & $1.89 \mathrm{c}$ & \\
\hline CV (\%) & 13.23 & & & & & & \\
\hline
\end{tabular}

Means followed by the same capital letter in the column and lowercase in the line did not differ statistically $(p<0.05)$.

density are highest at the surface, decreasing exponentially with depth. In the management of mechanical harvesting, sugarcane has $70-85 \%$ of its roots in the 0.00-0.40 m layer (Alvarez et al., 2000; Vasconcelos et al., 2003; Otto et al., 2009). The sugarcane root system may be active down to a depth of $2.0 \mathrm{~m}$, but root growth can continue and reach deeper layers (Smith et al., 2005).

In the average of the three management systems, the root diameter was lowest under the inter-row center (Table 4). This was due to the lower soil porosity, which limited the increase in root thickness. Queiroz-Voltan et al. (1998) also observed an effect of compaction on the anatomy of sugarcane roots, since the higher soil compaction affects the thickness of the cortex and vascular cylinder, which may reduce the root diameter.

The sugarcane productivity under managements TC1 and TC2 were higher (18.09 and $19.34 \%$, respectively) than of NTC (Table 5). The same was true for sugar yield, with an increase of 20.22 and $20.36 \%$ for TC1 and TC2, respectively. The higher productivity and sugar yield were due to the preservation of soil physical quality in the plant seedbed in the management systems with traffic control, allowing a greater root development (Table $4)$, reflected in the growth of the aerial part. These results agree with Braunack \& McGarry (2006), who observed an increase in sugarcane productivity and sugar yield in a management system with traffic control in Australia. Qingjie et al. (2009) also observed better soil physical conditions in the management with traffic control, increasing the average wheat yield by $6.9 \%$ than the random traffic (no traffic control).

The technological variables did not differ between the management systems, i.e., the amounts of cane fiber, total soluble solids, cane juice purity, apparent sucrose content and total recoverable sugars were similar among management systems with and without traffic control (Table 6). The greater soil compaction in the plant row in the management no traffic control could reduce the absorption of water and nutrients from the soil, due to the restricted root 
Table 4. Sugarcane root system under managements with traffic control consisting of the adjustment of the track width and use of an autopilot (TC2) and only adjusted track width (TC1) and no traffic control (NTC) measured in the plant row (PR), inter-row center (IRC) and seedbed (SB), in the studied layers

\begin{tabular}{|c|c|c|c|c|c|c|c|}
\hline \multirow{2}{*}{ Management system } & \multicolumn{3}{|c|}{ Sampling site } & \multicolumn{4}{|c|}{ Soil layer } \\
\hline & IRC & SB & PR & $0.00-0.10 \mathrm{~m}$ & $0.10-0.20 \mathrm{~m}$ & $0.20-0.30 \mathrm{~m}$ & Mean \\
\hline & \multicolumn{7}{|c|}{ Dry matter $\left(\mathrm{g} \mathrm{dm}^{-3}\right)$} \\
\hline CT2 & $0.158 \mathrm{Ab}$ & $0.378 \mathrm{Aab}$ & $0.664 \mathrm{Aa}$ & $0.510 \mathrm{Aa}$ & $0.395 \mathrm{Ab}$ & $0.295 \mathrm{Ac}$ & 0.400 \\
\hline $\mathrm{CT} 1$ & $0.134 \mathrm{Aa}$ & $0.313 \mathrm{Aa}$ & $0.357 \mathrm{Aa}$ & $0.316 \mathrm{Ba}$ & $0.271 \mathrm{Bab}$ & $0.217 \mathrm{ABb}$ & 0.268 \\
\hline NTC & $0.063 \mathrm{Aa}$ & $0.182 \mathrm{Aa}$ & $0.332 \mathrm{Aa}$ & $0.256 \mathrm{Ba}$ & $0.185 \mathrm{Bab}$ & $0.135 \mathrm{Bb}$ & 0.192 \\
\hline Mean & 0.119 & 0.291 & 0.451 & 0.361 & 0.284 & 0.216 & \\
\hline \multirow[t]{2}{*}{$\mathrm{CV}(\%)$} & 24.36 & & & & & & \\
\hline & \multicolumn{7}{|c|}{ Root diameter (mm) } \\
\hline $\mathrm{CT} 2$ & 1.062 & 1.197 & 1.223 & 1.159 & 1.097 & 1.227 & $1.161 \mathrm{~A}$ \\
\hline CT1 & 1.028 & 1.149 & 1.181 & 1.068 & 1.110 & 1.179 & $1.119 \mathrm{~A}$ \\
\hline NTC & 0.967 & 1.137 & 1.214 & 1.046 & 1.204 & 1.067 & $1.106 \mathrm{~A}$ \\
\hline Mean & $1.019 \mathrm{~b}$ & $1.160 \mathrm{a}$ & $1.206 \mathrm{a}$ & $1.091 \mathrm{a}$ & $1.137 \mathrm{a}$ & $1.158 \mathrm{a}$ & \\
\hline \multirow[t]{2}{*}{ CV (\%) } & 12.70 & & & & & & \\
\hline & \multicolumn{7}{|c|}{ Root density $\left(\mathrm{cm} \mathrm{dm}^{-3}\right)$} \\
\hline $\mathrm{CT} 2$ & $47.06 \mathrm{Ab}$ & $83.04 \mathrm{Aab}$ & $99.17 \mathrm{Aa}$ & 81.77 & 74.62 & 72.88 & $76.42 \mathrm{~A}$ \\
\hline CT1 & $46.33 \mathrm{Aa}$ & $71.20 \mathrm{Aa}$ & $68.14 \mathrm{Aa}$ & 63.88 & 58.44 & 63.36 & $61.89 \mathrm{~A}$ \\
\hline NTC & $25.27 \mathrm{Aa}$ & $46.93 \mathrm{Aa}$ & $62.64 \mathrm{Aa}$ & 48.12 & 40.30 & 46.42 & $44.95 \mathrm{~A}$ \\
\hline Mean & 39.55 & 67.05 & 76.65 & $64.58 \mathrm{a}$ & $57.79 \mathrm{a}$ & $60.89 \mathrm{a}$ & \\
\hline \multirow[t]{2}{*}{ CV (\%) } & 15.68 & & & & & & \\
\hline & \multicolumn{7}{|c|}{ Root surface $\left(\mathrm{cm}^{2} \mathrm{dm}^{-3}\right)$} \\
\hline $\mathrm{CT} 2$ & $16.49 \mathrm{Ab}$ & $29.91 \mathrm{Aa}$ & $35.02 \mathrm{Aa}$ & 29.99 & 26.36 & 25.24 & $27.20 \mathrm{~A}$ \\
\hline CT1 & $14.49 \mathrm{Aa}$ & $25.81 \mathrm{ABa}$ & $23.70 \mathrm{ABa}$ & 22.07 & 21.94 & 20.00 & $21.33 \mathrm{~A}$ \\
\hline NTC & $6.15 \mathrm{Ab}$ & 16.96 Bab & $21.97 \mathrm{Ba}$ & 18.08 & 13.98 & 13.02 & $15.02 \mathrm{~A}$ \\
\hline Mean & 12.37 & 24.23 & 26.96 & $23.38 \mathrm{a}$ & $20.76 \mathrm{ab}$ & $19.42 \mathrm{~b}$ & \\
\hline \multirow[t]{2}{*}{ CV (\%) } & 25.12 & & & & & & \\
\hline & \multicolumn{7}{|c|}{ Root volume $\left(\mathrm{cm}^{3} \mathrm{dm}^{-3}\right)$} \\
\hline $\mathrm{CT} 2$ & $0.565 \mathrm{Ab}$ & $1.420 \mathrm{Aa}$ & $1.600 \mathrm{Aa}$ & 1.375 & 1.110 & 1.100 & $1.195 \mathrm{~A}$ \\
\hline $\mathrm{CT} 1$ & $0.459 \mathrm{Ab}$ & $1.095 \mathrm{ABa}$ & $1.039 \mathrm{ABa}$ & 1.016 & 0.803 & 0.775 & $0.864 \mathrm{AB}$ \\
\hline NTC & $0.200 \mathrm{Ab}$ & $0.677 \mathrm{Bab}$ & $0.995 \mathrm{Ba}$ & 0.592 & 0.622 & 0.658 & $0.624 \mathrm{~B}$ \\
\hline Mean & 0.408 & 1.064 & 1.211 & $0.994 \mathrm{a}$ & $0.845 \mathrm{a}$ & $0.844 \mathrm{a}$ & \\
\hline CV (\%) & 30.73 & & & & & & \\
\hline
\end{tabular}

Means followed by the same capital letter in the column and lowercase in the line did not differ statistically $(p<0.05)$.

growth (Table 4), influencing the sugarcane technological quality (Meyer \& Wood, 2001). However, the adequate soil fertility, with the regionally recommended nutrients levels (Raij et al., 2001), together with favorable climatic conditions were sufficient to meet the crop demands, even under management without traffic control with reduced root development, without affecting the sugarcane technological quality (Meyer \& Wood, 2001). The results showed that the highest sugar yield in the management with traffic control is mainly associated with increased productivity rather than improvements in the quality of the raw material (Tables 5 and 6). These results agree with Braunack \& McGarry (2006), who reported that the commercial sugar yield per produced cane quantity $\left(139 \mathrm{~kg} \mathrm{Mg}^{-1}\right)$ was not affected by the management systems with and without traffic control. Wiedenfeld (2008) also stated that changes in soil quality did not affect the quality of the raw material of sugarcane in Texas.

The amounts of cane fiber, apparent sucrose content and cane juice purity were above the minimum levels recommended as quality threshold (Ripoli \& Ripoli, 2004), which is $11-13,>14$ and $>85 \%$, respectively (Table 6). Larrahondo et al. (2009) found values of cane fiber, apparent sucrose content, cane juice purity, and total soluble solids of $18 \%, 14.2 \%$, $84.9 \%$ and $16.7^{\circ}$ Brix, respectively, in sugarcane harvested mechanically in Colombia. Souza et al. (2005) analyzed 18 sugarcane varieties in São Paulo, 
found mean values of cane fiber, cane juice purity, apparent sucrose content and total recoverable sugars of $91 \%, 11 \%, 18 \%$ and $168 \mathrm{~kg} \mathrm{Mg}^{-1}$, respectively, in a management where the cane trash was left unchopped on the soil surface, similar to this study.

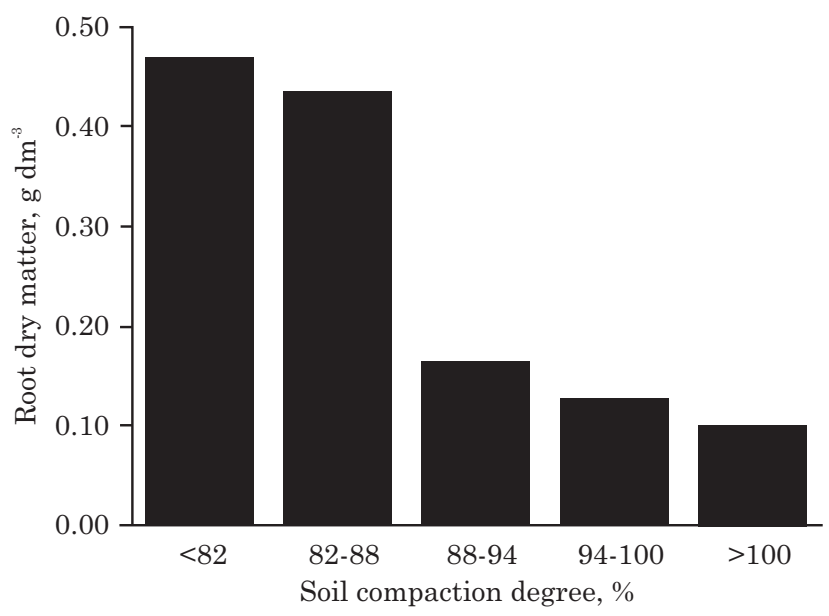

Figure 1. Distribution of sugarcane root dry matter according to the soil compaction degree in management systems.

Table 5. Sugarcane productivity and sugar yield under managements with traffic control with adjusted track width and use of an autopilot (TC2) and only adjusted track width (TC1) and with no traffic control (NTC)

\begin{tabular}{lcccc}
\hline $\begin{array}{c}\text { Management } \\
\text { system }\end{array}$ & \multicolumn{2}{c}{ Productivity } & \multicolumn{2}{c}{ Sugar yield } \\
\hline & $\mathrm{Mg} \mathrm{ha}^{-1}$ & $\%$ & $\mathrm{Mg} \mathrm{ha}^{-1}$ & $\%$ \\
$\mathrm{CT} 2$ & $126.45 \mathrm{~A}$ & 119.34 & $17.62 \mathrm{~A}$ & 120.36 \\
$\mathrm{CT} 1$ & $124.96 \mathrm{~A}$ & 118.09 & $17.60 \mathrm{~A}$ & 120.22 \\
$\mathrm{NTC}$ & $105.82 \mathrm{~B}$ & 100.00 & $14.64 \mathrm{~B}$ & 100.00 \\
CV (\%) & 11.38 & & 7.72 & \\
\hline
\end{tabular}

Means followed by the same capital letter in the column did not differ statistically $(\mathrm{p}<0.05)$.

\section{CONCLUSIONS}

1. The management system with traffic control, based on the adjustment of the track width of tractortrailer set and the use of an autopilot preserved the soil physical quality in the plant rows and resulted in greater compaction under the inter-row center.

2. Management systems to control traffic based on an adjustment of the track width of the tractortrailer set, with or without the use of the autopilot, allowed the best cane root development in the plant rows and in the seedbed region.

3. The soil compaction degree above $93 \%$, corresponding to a bulk density of $1.30 \mathrm{Mg} \mathrm{m}^{-3}$, severely restricted the sugarcane root development.

4. The management systems with traffic control led to an increase in sugarcane productivity of $18.72 \%$ and of sugar yield of $20.29 \%$, without improvements in technological variables compared to the management no traffic control.

\section{ACKNOWLEDGEMENTS}

The authors are indebted to the Usina São Martinho for granting access to the study area, to the National Council for Scientific and Technological Development (CNPq) for the scholarship to the first author and to State of São Paulo Research Foundation (FAPESP) for funding the project (No. 2008/09232-3).

\section{LITERATURE CITED}

ALAMEDA, D.; ANTEN, N.P.R. \& VILLAR, R. Soil compaction effects on growth and root traits of tobacco depend on light, water regime and mechanical stress. Soil Till. Res., 120:121-129, 2012.

ALVAREZ, I.A.; CASTRO, P.R.K. \& NOGUEIRA, M.C.S. Crescimento de raízes de cana crua e queimada em dois ciclos. Sci. Agric., 57:653-659, 2000.

Table 6. Technical quality of sugarcane in managements with traffic control with adjusted track width and use of an autopilot (TC2) and only adjusted track width (TC1) and check treatment without traffic control (NTC)

\begin{tabular}{|c|c|c|c|c|c|}
\hline Management system & Fiber & Brix & Purity & ASC & TRS \\
\hline & $\%$ & ${ }^{\circ}$ brix & +2 & 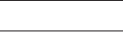 & $\mathrm{kg} \mathrm{Mg}^{-1}$ \\
\hline $\mathrm{CT} 2$ & $11.66 \mathrm{~A}$ & $18.45 \mathrm{~A}$ & $89.74 \mathrm{~A}$ & $14.46 \mathrm{~A}$ & $142.24 \mathrm{~A}$ \\
\hline CT1 & $11.72 \mathrm{~A}$ & $18.70 \mathrm{~A}$ & $89.02 \mathrm{~A}$ & $14.48 \mathrm{~A}$ & $142.19 \mathrm{~A}$ \\
\hline NTC & $11.42 \mathrm{~A}$ & $18.51 \mathrm{~A}$ & $89.58 \mathrm{~A}$ & $14.57 \mathrm{~A}$ & $143.19 \mathrm{~A}$ \\
\hline Mean & 11.60 & 18.55 & 89.45 & 14.50 & 142.54 \\
\hline $\mathrm{CV}(\%)$ & 3.39 & 1.22 & 0.85 & 1.38 & 1.32 \\
\hline
\end{tabular}

Means followed by the same capital letter in the column did not differ statistically $(\mathrm{p}<0.05)$. Fiber: cane fiber; Brix: total soluble solids; Purity: cane juice purity; ASC: apparent sucrose content; and TRS: total recoverable sugars. 
BRAUNACK, M.V. \& McGARRY, D. Traffic control and tillage strategies for harvesting and planting of sugarcane (Saccharum officinarum) in Australia. Soil Till. Res., 89:86$102,2006$.

CAMARGO, O.A.; MONIZ, A.C.; JORGE, J.A. \& VALADARES, J.M.A.S. Métodos de análise química, mineralógica e física de solos do Instituto Agronômico de Campinas. Campinas, Instituto Agronômico de Campinas, 1986. 94p.

CARTER, M.R. Relative measures of soil bulk density to characterize compaction in tillage studies on fine sandy loams. Can. J. Soil Sci., 70:425-433, 1990.

CAVALIERI, K.M.V.; CARVALHO, L.A.; SILVA, A.P.; LIBARDI, P.L. \& TORMENA, C.A. Qualidade física de três solos sob colheita mecanizada de cana-de-açúcar. R. Bras. Ci. Solo, 35:1541-1549, 2011.

CONSELHO DOS PRODUTORES DE CANA-DE-AÇÚCAR, AÇÚCAR E ÁLCOOL DO ESTADO DE SÃO PAULO CONSECANA. Manual de instruções. Piracicaba, 2006. 54p.

EMPRESA BRASILEIRA DE PESQUISA AGROPECUÁRIA EMBRAPA. Centro Nacional de Pesquisa de Solos. Manual de métodos de análise de solo. 2.ed. Rio de Janeiro, 1997. $212 \mathrm{p}$.

EMPRESA BRASILEIRA DE PESQUISA AGROPECUÁRIA EMBRAPA. Centro Nacional de Pesquisa de Solos. Sistema brasileiro de classificação de solos. 2.ed. Rio de Janeiro, 2006. 306p.

KEMPER, W.D. \& CHEPIL, W.S. Size distribution of aggregates. In: BLACK, C.A., ed. Methods of soil analysis. Madison, American Society Agronomy, 1965. p.499-510.

KINGWELL, R. \& FUCHSBICHLER, A. The whole-farm benefits of controlled traffic farming: An Australian appraisal. Agric. Syst., 104:513-521, 2011.

LAGUË, C.; AGNEW, J. \& KHELIFI, M. Theoretical evaluation on the feasibility of Controlled-Traffic Farming (CTF). Montréal, Using Wide-Span Implement Carriers (WSIC) for Canadian Agriculture, 2003. (CSAE - Paper No 03-233)

LARRAHONDO, J.E.; CASTILLO, E.F.; PERALTA, Y.; JARAMILLO, A.; PALMA, A.; BRICEÑO, C. \& GIRALDO, F. Impact of extraneous matter on post-harvest sucrose losses and quality parameters in sugarcane. Sugar Technol., 11:171-175, 2009.

MATERECHERA, S.A. Tillage and tractor traffic effects on soil compaction in horticultural fields used for peri-urban agriculture in a semi-arid environment of the North West Province, South Africa. Soil Till. Res., 103:11-15, 2009.

McHUGH, A.D.; TULLBERG, J.N. \& FREEBAIRN, D.M. Controlled traffic farming restores soil structure. Soil Till. Res., 104:164-172, 2009.

MEYER, J.H. \& WOOD, R.A. The effects of soil fertility and nutrition on sugarcane quality: A review. South African Sugar Technol. Assoc., 75:242-247, 2001.

NEVES, C.S.V.J.; FELLER, C.; GUIMARÃES, M.F.; MEDINA, C.C.; TAVARES FILHO, J. \& FORTIER, M. Soil bulk density and porosity of homogeneous morphological units identified by the cropping profile method in clayey Oxisols in Brazil. Soil Till. Res., 71:109-119, 2003.
OTTO, R.; SILVA, A.P.; FRANCO, H.C.J.; OLIVEIRA, E.C.A. \& TRIVELIN, P.C.O. High soil penetration resistance reduces sugarcane root system development. Soil Till. Res., 117:201-210, 2011.

OTTO, R.; TRIVELIN, P.C.O.; FRANCO, H.C.J.; FARONI, C.E. \& VITTI, A.C. Root system distribution of sugar cane as related to nitrogen fertilization, evaluated by two methods: Monolith and probes. R. Bras. Ci. Solo, 33:601-611, 2009.

PAULINO, A.F.; MEDINA, C.C.; AZEVEDO, M.C.B.; SILVEIRA, K.R.P.; TREVISAN, A.A. \& MURATA, I.M. Escarificação de um Latossolo Vermelho na pós-colheita de soqueira de cana-de-açúcar. R. Bras. Ci. Solo, 28:911917, 2004.

QINGJIE, W.; HAO, C.; HONGWEN, L.; WENYING, L.; XIAOYAN, W.; McHUGH, A.D.; JIN, H. \& HUANWEN, G. Controlled traffic farming with no tillage for improved fallow water storage and crop yield on the Chinese Loess Plateau. Soil Till. Res., 104:192-197, 2009.

QUEIROZ-VOLTAN, R.B.; PRADO, H. \& MORETTI, F.C. Aspectos estruturais de raízes de cana-de-açúcar sob o efeito da compactação do solo. Bragantia, 57:49-55, 1998.

RAIJ, B.van.; ANDRADE, J.C.; CANTARELLA, H. \& QUAGGIO, J.A. Análise química para avaliação da fertilidade de solos tropicais. Campinas, Instituto Agronômico de Campinas, 2001. 285p.

REICHERT, J.M.; SUZUKI, L.E.A.S.; REINERT, D.J.; HORN, R. \& HÅKANSSON, I. Reference bulk density and critical degree-of-compactness for no-till crop production in subtropical highly weathered soils. Soil Till. Res., 102:242254, 2009.

RIPOLI, T.C.C. \& RIPOLI, M.L.C. Biomassa de cana-de-açúcar: Colheita, energia e ambiente. Piracicaba, Barros \& Marques Eletrônica, 2004. 302p.

ROQUE, A.A.O.; SOUZA, Z.M.; BARBOSA, R.S. \& SOUZA, G.S. Controle de tráfego agrícola e atributos físicos do solo em área cultivada com cana-de-açúcar. Pesq. Agropec. Bras., 45:744-750, 2010.

SAS Institute. SAS/STAT user's guide: Statistics. Versão 9.2. Cary, 2008.

SEVERIANO, E.C.; OLIVEIRA, G.C.; DIAS JÚNIOR, M.S.; OLIVEIRA, L.F.C. \& CASTRO, M.B. Pressão de preconsolidação e intervalo hídrico ótimo como indicadores de alterações estruturais de um Latossolo e de um Cambissolo sob cana-de-açúcar. R. Bras. Ci. Solo, 32:14191427,2008

SMITH, D.M.; INMAN-BAMBER, N.G. \& THORBURN, P.J. Growth and function of the sugarcane root system. Field Crops Res., 92:169-183, 2005.

SOUZA, Z.M.; MARQUES JÚNIOR, J.; COOPER, M. \& PEREIRA, G.T. Micromorfologia do solo e sua relação com atributos físicos e hídricos. Pesq. Agropec. Bras., 41:487-492, 2006.

SOUZA, Z.M.; PRADO, R.M.; PAIXÃO, A.C.S. \& CESARIN, L.G. Sistemas de colheita e manejo da palhada de canade-açúcar. Pesq. Agropec. Bras., 40-271-278, 2005. 
STOLF, R. Teoria e teste experimental de fórmulas de transformação dos dados de penetrômetro de impacto em resistência do solo. R. Bras. Ci. Solo, 15:229-235, 1991.

SOIL SURVEY STAFF. Keys to soil taxonomy. 11.ed. Washington, USDA-Natural Resources Conservation Service, 2010.

STRECK, C.A.; REINERT, D.J.; REICHERT, J.M. \& KAISER, D.R. Modificações em propriedades físicas com a compactação do solo causada pelo tráfego induzido de um trator em plantio direto. Ci. Rural, 34:755-760, 2004.

TULLBERG, J.N.; YULE, D.F. \& McGARRY, D. Controlled traffic farming - from research to adoption in Australia. Soil Till. Res., 97:272-281, 2007.

VASCONCELOS, A.C.M.; CASAGRANDE, A.A.; PERECIN, D.; JORGE, L.A.C. \& LANDELL, M.G.A. Avaliação do sistema radicular da cana-de-açúcar por diferentes métodos. R. Bras. Ci. Solo, 27:849-858, 2003.
VERMEULEN, G.D. \& MOSQUERA, J. Soil, crop and emission responses to seasonal-controlled traffic in organic vegetable farming on loam soil. Soil Till. Res., 102:126134, 2009.

VEZZANI, F.M. \& MIELNICZUK, J. Agregação e estoque de carbono em Argissolo submetido a diferentes práticas de manejo agrícola. R. Bras. Ci. Solo, 35:213-223, 2011.

WENDLING, B.; JUCKSCH, I.; MENDONÇA, E.S. \& NEVES, J.C.L. Carbono orgânico e estabilidade de agregados de um Latossolo Vermelho sob diferentes manejos. Pesq. Agropec. Bras., 40:487-494, 2005.

WIEDENFELD, B. Effects of irrigation water salinity and electrostatic water treatment for sugarcane production. Agric. Water Manage., 95:85-88, 2008.

XU, X.; NIEBER, J.L. \& GUPTA, S.C. Compaction effects on the gas diffusion coefficients in soil. Soil Sci. Soc. Am. J., $56: 1743-1750,1992$. 